\title{
The many voices in a Muslim self
}

\author{
Dialogical self theory in conceptualizing the religious identities \\ and authorities of young European Muslims
}

DOI: https://doi.org/10.30664/ar.110855

(c) Attribution 4.0 International (CC BY 4.0)

P revious research has demonstrated that young European Muslims relate to religion and religious authority differently from their parental generation. While traditional 'ulama (Islamic scholars) are not about to become obsolete, they are nevertheless increasingly forced to defend their status against competitors. Furthermore, the relationship between many young Muslims and established religious authority is marked by ambivalence and complexity. In this article, I suggest the dialogical self theory (DST) as a fruitful approach to conceptualizing the religious identities and authorities of young European Muslims. To illustrate DST, I present a case study of a young Shi'a Muslim who adopts two rather different positions towards religion. The position of 'Doubting Sara' is characterized by an independent search for an intellectually and ethically satisfactory worldview. In turn, the position of 'Pious Sara' emphasizes the peace of mind that is provided by routine religious practices. Together, 'Doubting Sara' and 'Pious Sara' maintain a balance that enables both religious stability and growth.

\section{Introduction}

Over the past two decades, researchers have devoted much attention to the religious change that is supposedly occurring among young European Muslims (for a review, see Duderija 2007; Pauha 2018: 15-23; Voas and Fleischmann 2012). ${ }^{1}$ The buzzwords

1 By 'young European Muslims', I mean primarily those Muslims whose parents of this line of inquiry include individualization, objectification and globalization. Young Muslims increasingly perceive their religious identity as an individual choice. In their view, individuals can, and must, decide for themselves what it means to be a Muslim. At the same time, Islam is being perceived as a distinct object of knowledge that is separate from other areas of life. This objectified conception of Islam is built on the idea of a universal core that unites the geographically and historically diverse forms of belief and practice.

Changes in the production of religious knowledge will inevitably affect also the role and status of religious authorities. Indeed, a number of scholars have identified what Christine Jacobsen (2011: 225) has called 'a gradual erosion of the position of the traditional ulema'(Islamic scholars).

were born and raised in Muslim-majority countries but who themselves have grown up in Western and Northern Europe. This group of people has been the focus of most research attention, and accordingly, the results presented here apply primarily to them. Of course, there are also other young European Muslims who may be characterized by different identity dynamics. In the Finnish context, these include especially converts and the Tatars. 
The narrative of a loss of status among traditional religious authorities is so common that, according to a review article by Frank Peter (2006: 107), 'the declining influence of "classical" Islamic institutions (mosques, imams, etc.) as a result of the profound generational changes has by now become an almost unquestioned truth in research on Western European Islam'.

However, more recent studies have complicated the picture. Studies such as those of Hira Amin (2019), Amin El-Yousfi (2019) and Muhammed Tajri (2016) suggest a simple downward slope is much too simplistic a way to characterize the change in the status of the established Islamic authorities. Generally speaking, and contrary to a common narrative, young European Muslims are not rejecting or ignoring the traditional Islamic authorities en masse. Instead, young Muslims still hold the established authorities in high esteem while at the same time feeling entitled to comment, criticize or challenge them.

The question that I address in this article is how to conceptualize the complex relationship that many young European Muslims seem to have with religious authority and its effects on identity construction. The solution that I propose is the dialogical self theory (DST), originally proposed by Hubert Hermans and colleagues (Hermans et al. 1992). I introduce the main tenets of DST as they appear in interview data gathered from a young Muslim who participated in my research project on the role of the Qur'an in the everyday lives of Shi'a youth in Finland. The young Muslim, whom I call 'Sara', negotiated her religious identity in dialogue with a variety of both established and alternative authorities. It is worth emphasizing that her case is intended to exemplify a theoretical and methodological approach and not to be representative of Muslim youth at large. However, as noted below, similar dynamics appear in other interviews conducted during the same project. 'Sara' is exceptional primarily in the clarity with which she expresses her identity negotiations and conflicts.

\section{Negotiating with authority}

Bricolage is a term that is commonly used to describe the processes of identity construction both among young European Muslims and more generally. Deriving from the work of Claude Lévi-Strauss (1962), bricolage refers to construction processes that involve materials derived from a variety of sources. For example, a young Muslim may fashion their religious identity by combining ideas and influences drawn from 'ulama and other traditional authorities, social media, literature, scientific and philosophical thinkers, family members, classmates, etc.

Hira Amin (2019) has elaborated on the notion of bricolage by discussing religious choice together with self-restriction. According to Amin, British Muslims exercize their own judgement in choosing the scholars that they consider as representing authentic Islam. This initial determination of proper authorities then sets the boundary conditions for the future bricolage. Rather than being completely unrestricted in their religious meaning-making, young Muslims thus self-impose criteria that regulate which advice is to be followed and which is to be discarded.

It is worth mentioning here that, especially with regard to Sunni Islam, the plurality of religious authorities is nothing new. Apart from the textual authority of the Qur'an and prophetic example, Sunni Islam has never had a centralized authority nor an established religious hierarchy. Therefore, and as pointed out by Peter Mandaville (2007: 102), the current situation is perhaps best seen as an intensification of a 
tendency towards decentralized authority that has always been present in Islam'.

Instead of being at the relative bottom of a fixed religious hierarchy, young Muslims are involved in complex networks of religious power and knowledge. Furthermore, the relationship of young European Muslims to religious authority has become increasingly dialogical. Despite committing themselves to the authority of certain scholars, the British Muslims studied by Amin (2019) were not hesitant to comment on their views and to give feedback.

Compared with Sunni Islam, Twelver Shi'ism has a more distinct religious hierarchy with several levels of authority. Maraji al-taqlid (sing. marja' al-taqlid), or the sources of emulation, constitute the highest level in the Twelver Shi'a religious hierarchy. Every believer who is not a religious scholar is expected to choose a marja' and to adhere to their rulings in religious matters (Walbridge 2001: 3-4). Indeed, Muhammed Tajri (2016) found in his study that young British Shi'a associate the term 'religious authority' first and foremost with the maraji al-taqlid that reside in the Middle East, especially in the cities of Najaf in Iraq and Qom in Iran. However, Tajri's (2016) interlocutors expressed a pronounced ambivalence towards their maraji. On one hand, the interlocutors respected the maraji and felt obedient to them. On the other hand, the interlocutors did not hesitate to criticize the maraji, sometimes in a markedly harsh manner. The crucial point of criticism was that the rulings of Iranian and Iraqi scholars were perceived as being out of touch with the lived realities in the British society.

\section{The need for a dialogical approach to religious authority}

Gudrun Kramer and Sabine Schmidtke (2006: 1-2) have defined religious authority as 'the ability to have one's rules and rulings followed, or obeyed, without recourse to coercive power ... [and] to compose and define the canon of "authoritative" texts and the legitimate methods of interpretation'. Psychologists have studied religious authority above all in terms of leadership and persuasion (see e.g. Dawson 2006; Wright 2008). In turn, in the sociology of religion, Max Weber's work on the three forms of legitimacy (traditional, charismatic and legal) has provided the dominant paradigm (see e.g. Campbell 2007; Hjarvard 2016; Stephenson 2011; Rinallo et al. 2016; Takim 2006). However, these approaches are limited in that they consider only one actor (the leader), or at most two (the leader and the follower), of an authority relationship. In this article, I argue that the dialogical self theory (DST) of Hubert Hermans and his colleagues provides an approach that can capture a more comprehensive view of the web of religious authority and the relationships between its knots. The core idea of DST is that the self is 'a dynamic multiplicity of relatively autonomous I positions' (Hermans 1999: 1197), which 'function like interacting characters in a story, involved in a process of question and answer, agreement and disagreement' (Hermans 2001: 248). In other words, the personal self is not a single, unified entity, but more akin to a group of distinct actors that are engaged in a dialogue with each other.

Furthermore, the ambivalence that Tajri's (2016) young Shía interlocutors expressed towards maraji suggests that young Muslims are engaged in dialogues that are, on one hand, between themselves and religious leaders and, on the other 
hand, within themselves. Accordingly, in order to have a more comprehensive view of the ways in which young Muslims form their religious identities, we require an approach that deals with both intra- and interpersonal negotiations over religious authority.

Researchers operating in the framework of DST have identified and described various types of I-positions that may participate in a dialogical self (see e.g. Hermans and Gieser 2011; Raggatt 2011). Most importantly, the positions can be divided into internal and external, the former being experienced as originating from inside one's own person and as voicing one's own views and values; the latter, in turn, represent the internalized or imaginary voices of other people (Grimell 2018: 195; Hermans 2014). For example, when being engaged in an ethically questionable activity, a person may imagine the judgemental voice of their parent commenting on their actions. In the Islamic discursive tradition (Asad 2017), a key external position is the Prophet Muhammad, whose sayings and deeds serve as a model for other believers to follow.

A special class of external positions are the collective positions, such as Finns or Muslims (Hermans 2001: 248). In their identity work, people often orient themselves to what they perceive to be a common view among 'us Muslims', 'us psychologists', 'us immigrants', etc. A central argument in this article is that conceptualizing religious authorities as external I-positions increases our understanding of the ways in which young European Muslims construct their identities in relation to them.

Researchers have also classified I-positions on the basis of the function they perform in the dialogical self (Hermans and Gieser 2011; Raggatt 2011). I would mention especially the so-called third positions, the function of which is to mediate between two conflicting I-positions (Hermans and Gieser 2011: 25-6; Pauha and Ronkainen 2021; Raggatt 2011). Compared with many other approaches, DST considers the unification of identity to be of less importance (Hermans 1996; Thorne 2004: 363). A dialogical self is multi-voiced by nature and therefore also prone to internal division. As I argue in this article, some level of tension within the self may even be conducive to mature religiosity. If there is a power balance between I-positions and each position is afforded an opportunity to satisfy its needs, the existence of diverse voices within the self may well support mental flexibility and a psychologically rich life. In contrast, if one voice becomes hegemonic in a dialogical self, it may lead to suppression of basic needs (Nir 2011: 256). In the latter case, a third position may be introduced to remedy the situation (cf. Pauha and Ronkainen 2021).

I emphasize that I-positions are not roles in the sense of being socially structured and situational behaviour patterns under which a true self is hidden. There is no true self apart from the I-positions. Instead, and even in an ontological sense, the self $i s$ the dialogue among the positions (cf. Hermans and Gieser 2011: 18).

\section{The present study}

In this article, I apply the dialogical self theory to the analysis of the interview account of one young Muslim whom I have interviewed for my research project on the role of the Qur'an in the everyday lives of young Shi'a Muslims. In the project, I approach the Qur'an on one hand as a symbolic resource (see the section 'Symbolic resources in the service of selfmaking') that young Muslims use to negotiate their religious identities and regulate their emotions, while, on the other hand, I 
perceive the Qur'an as one knot in a complex web of religious authorities in a young Muslim's life. In my project, I am interested in the folk hermeneutics (cf. Bialecki 2009: 145) that young Muslims apply to reading the Qur'an. I also seek to understand how such hermeneutics are informed by a dialogue with various others, for example, parents and teachers. My conception of Islam and religion more generally is informed by research conducted on 'everyday' or 'lived' religion (see e.g. Ammerman 2007; Dessing et al. 2013; Hall 1997; McGuire 2008; Reinhart 2020; Schielke and Debevec 2012). I am thus interested in the everyday practices that involve the Qur'an, and do not attempt to measure such practices against any kind of notion of 'orthodox' Islam.

For the past two years, I have conducted ethnographic investigation among the Shi'a in Finland. I have participated in the activities of Shi'a communities, observed them on social media, and interviewed their members as well as other young people who identify themselves as Shía. ${ }^{2}$ The interview protocol is semi-structured and includes questions such as: 'What is for you the most important message of the Qur'an?', 'Have you had problems in understanding some passage? If so, was there anything that

2 Samuli Schielke (2010: 2) has pointed out that much of the research on Islam is conducted with religiously active people in religious contexts. This in turn may lead to there being 'too much Islam in the anthropology of Islam' In order to avoid this pitfall, I have very purposefully sought interviewees who identify themselves as Shi'a but are not active participants in any mosque or Islamic association. Furthermore, I have conducted the interviews in a non-religious setting, most often at the university (cf. Brekke et al. 2019). Many of my interviewees are university students and have thus preferred university as a location. helped you to understand it later?' However, these questions serve primarily as a checklist to ensure that the most relevant topics are discussed. The questions are not asked in a fixed order or with a fixed wording. The only exception is the first question, which is always: 'If you had to describe in one sentence what the Qur'an means to you, what would you say?' The interviewer then picks up on any theme raised by the respondent and prompts them to elaborate on it. The interviews are recorded and transcribed verbatim. At the end of the project, the anonymized transcripts will be deposited at the Finnish Social Science Data Archive (FSD), where they are available to other researchers.

The duration of the interviews has been between 65 and 125 minutes, with the average being around 90 minutes. So far, my interviewees have included twelve young Muslims, six of whom have been women. In this article, I focus on the interview account of one of them, 'Sara'. I have chosen to focus on this one particular interview because it illustrates well the identity dynamics in which I am interested. Sara was certainly not the only interviewee who constructed her identity in a reflective dialogue with a plurality of religious authorities and influences. However, her account was exceptional in how sharply the contrast between different dialogical positions manifested itself. In her interview, Sara made explicit the tensions that were implicit in most of the other interviews. Sara's account thus provides the clearest illustration of the potential of DST for conceptualizing the complex relations between European Muslim identity and religious authority.

Sara is in her twenties and a full-time student. She contacted me after hearing of my project from a friend and volunteered to be interviewed. The interview 
was conducted in Finnish. The interview excerpts on the following pages are my own translations. In the analysis, I have adhered to the principles of negotiational self method (NSM), originally proposed by Dina Nir (2011) and developed further by Teemu Pauha and Noora Ronkainen (2021).

NSM is a procedure specifically designed to identify and describe tensions within the dialogical self. The method was originally intended for counselling purposes but it has also been applied to research (Pauha and Ronkainen 2021). NSM analysis involves several stages that I will describe in more detail in the following sections.

\section{Shi'a in Finland}

Before proceeding to the analysis, it is worthwhile to briefly describe the research context. According to the latest estimates, there are 120,000-130,000 Muslims in Finland, of whom as many as one quarter may be Shía (Pauha and Nikanne 2022). The Finnish Muslims in general and the Shi'a in particular are predominantly first generation immigrants who have arrived in the country as refugees or through family reunification. The Shía in Finland are primarily of Iraqi, Afghani, Iranian, or Pakistani background. A sizeable share of the Afghani in Finland are Hazaras, and therefore also Shi'a (Pauha and Bahmanpour forthcoming).

At the moment there are approximately ten registered Shi'a communities, the largest of which is the Resalat Islamic Society (Resalat Islamilainen Yhdyskunta) with its 800 members. The youth group Mahdin Nuoret is officially independent but in practice closely affiliated with Resalat. With regard to religious authority, Ayatollahs Khamenei, Sistani, and Makarem Shirazi are worth mentioning for the large following that they enjoy among the Finnish Shi'a (Pauha and Bahmanpour forthcoming).

Living in Finland as a religious minority, young Shi'a Muslims encounter a marked religious diversity. Such a setting is conducive to increased reflection and reinterpretation of one's own religious tradition (cf. Flaskerud 2018). This kind of reflection is further supported by the low level of restrictions on religious practice and Internet use. Young Muslims are able to access a variety of information that they can use as raw materials for identity construction. To some extent, it is even socially normative to explore the various lifestyle options that are available before making a commitment to any of them.

\section{Key divisions in the religious self}

The first stage of NSM is the identification of a central conflict. In Sara's case, the central conflict is rather obvious; it is in the fourth minute of a 108-minute interview that she spontaneously starts talking about 'a massive identity crisis'. At first, Sara refers to the identity crisis as a teenage experience. However, only a little later, she confesses that the same issues still trouble her:

Well, the religion and all these other things. One starts to think, for example, why am I wearing a scarf in Finland? That was one thing that started to puzzle me. Or the status of women in the religion of Islam. And the other things as well, like the terrorist organizations. All these things made me wonder how is this, how is this in practice? How can the Qur'an that for me is about peace and peace of mind, how can it make another person terrorize or harm other people? Those kinds of questions started to go around in my head. 
Sara perceives the Quran both as a source of comfort and peace of mind and as a potential instrument of exclusion and violence. She returns to this key conflict time and again during the interview.

The second stage of NSM involves outlining the conflict-relevant I-positions. After determining the poles of the conflict, I investigated in detail the voice that identified with each respective pole. I analysed the values, assumptions and influences that underlay the view of the Qur'an as a source of comfort or, alternatively, as an instrument of oppression. Imagining the interview account as a dialogue between several people with varying views on the Qur'an, I tried to understand what kind of people held these said views.

In Sara's case, the main conflict appeared to be between two I-positions that I have called 'Doubting Sara' and 'Pious Sara'. For 'Pious Sara', the primary function of religion is to provide help in times of trouble. This help is especially of an emotional nature. When I asked Sara to describe her relationship to the Qur'an in one sentence, she replied with a single word: mielenrauhaa (peace of mind). She returns to the same topic throughout the interview, even describing the attainment of peace of mind as the primary goal underlying all religiosity. Towards the end of the interview, Sara says that what she gets from the Qur'an is an ability to live. She appears to mean this quite literally, because the very next thing that she speaks of is suicide. Sara contrasts the high suicide rate in Finland and other Western countries with the lower rate in the Middle East, and explains the difference in terms of higher average religiosity in the Middle Eastern countries:

In my opinion it is the strong trust and faith that the people in the Middle East have that makes people live regardless of how difficult life is.... When you look at videos or documentaries about them, you see how positive they are. And when you look at that positivity and how they are living with it, you are left speechless. But in the Western countries, for example here in Finland, the suicide rates are really high and it is really sad to think about the things that drive people to the point at which they take their own life.

Just a little later, and in a striking contrast to how she portrayed Middle Easterners in the previous excerpt, Sara makes a comment about religion in Iran:

It's been the political situation in Iran that has kind of, or the Ministry of Education in Iran that focuses on the control they have. So it is a kind of a wrong image that they have presented to the children. And precisely that has caused in Iran the situation where people are hating the religion and do not want to have anything to do with any kind of religion.

The comment is characteristic of the I-position that I have named 'Doubting Sara'. Compared to 'Pious Sara', 'Doubting Sara' is much more critical towards religion. Besides Iranian politics, her criticism is directed towards the intertwining of religion and politics more generally, as well as towards religiously justified homophobia and misogyny.

\section{Voices of others in the self}

'Doubting Sara' and 'Pious Sara' are the two main internal I-positions in Sara's position repertoire. They are 'internal' in the sense of being referred to in the first person singular and thus being discursively owned. However, in addition to the two internal 
I-positions, Sara has a number of external I-positions that participate in her identity narration. In other words, Sara's dialogical self includes voices that she attributes to other people.

Sara introduces a key external I-position - namely her grandmother - in the very first minutes of the interview. When asked whether she owns a copy of the Qur'an herself, Sara responds that she uses a Qur'an that her late grandmother gave her as a gift when she was a child. Besides this Qur'an, Sara has another copy that she has also received as a gift but cannot recall from whom. In a slight contradiction to her previous response, Sara says that she prefers to use the latter copy because it is smaller in size and has a better parallel translation in Persian.

The contradiction regarding which copy Sara likes to use parallels a difference in attitudes between 'Doubting Sara' and 'Pious Sara. 'Doubting Sara' approaches religion cognitively and rationally. For her, it is important to understand the meaning of the Quranic text. Therefore, a good translation is a priority for 'Doubting Sara', and it is of less importance who has given it to her.

In contrast, 'Pious Sara' has a strong emotional and social bond with her religious tradition. For 'Pious Sara', Islamic practices are closely associated with the childhood relationships in which she acquired them. According to Sara, she was exceptionally close to her grandmother, and because of this, a copy of the Qur'an given by her is invaluable. Memories of the grandmother endow the Qur'an with meaning.

For 'Pious Sara', the grandmother also serves as a religious authority, or more specifically, a role model. In Sara's own words, the grandmother did not 'study' the Qur'an but 'just read' it. Similarly, Sara gets through a difficult period in her life by 'just reading' the Qur'an:
I did not go about reading then with the thought that ... what does this translation mean, but I just read the Qur'an. And it was reading the Qur'an that helped me in the situation. ... Then, it was just nice to read, or not so much nice but empowering and really positive and really helpful.

Besides the grandmother, other family members also feature in Sara's dialogical self. Of particular importance to 'Doubting Sara' are her father and brother. Sara describes her childhood family as one in which it is 'allowed to question all kinds of things out loud'. Sara says that she tends to ask her father about Islamic positions that she finds difficult to understand. Laughing, she adds that this sometimes leads to a 'massive argument'. However, she finds the discussions with her father to be 'quite reasonable' overall. For example, suggestions from her father have led her to familiarize herself with Abdolali Bazargan and other progressive thinkers. Sara's brother in turn is her companion on a quest for religious answers:

And my brother, for example - he keeps asking me a lot of things. Or else we think about them together. He's young as well, and grew up here, and because of that he's also wondering about the same kind of questions. ... And you don't get reasonable answers to these questions anywhere! Well, yeah, and when there's no one likeminded around, it's a bit difficult to go into these things along with other people. So, we think about things, with my brother for example.

Besides Abdolali Bazargan, Sara mentions by name two other thinkers who have been influential for her religious identity: 


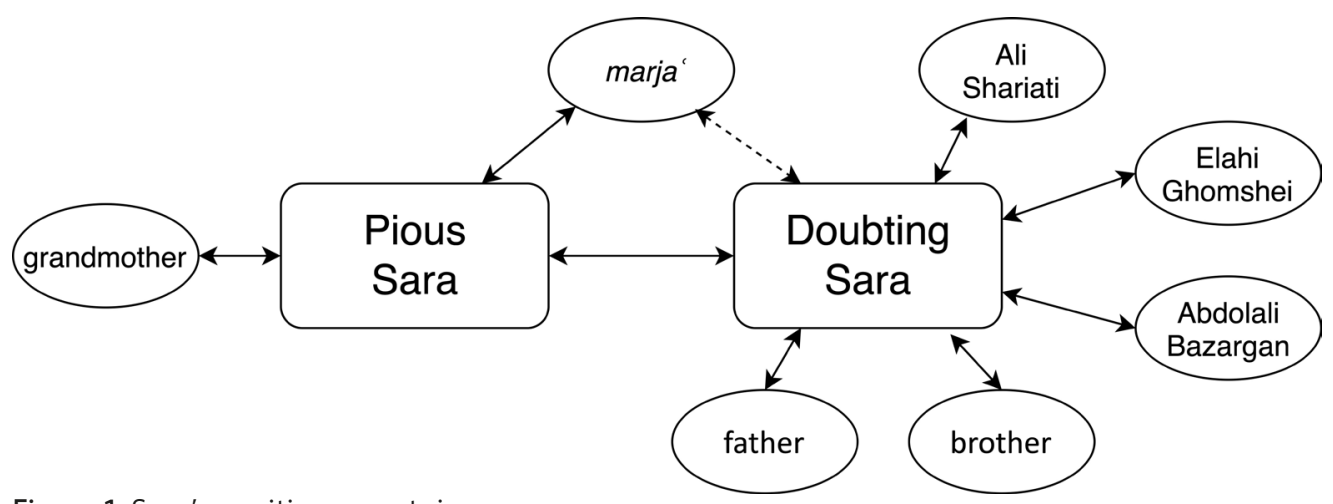

Figure 1. Sara's position repertoire

Ali Shariati and Elahi Ghomshei. When Sara's 'identity crisis' was most acute, the former provided answers that eased her mind, at least temporarily. Reading Ali Shariati, Sara understood that despite its proclamations of gender equality, the West is hardly a model for others to follow. Furthermore, she came to a conclusion that the oppressive aspects of the Islamic tradition are traces of the past and will fade away with time. In turn, Elahi Ghomshei has provided support for a view that is central to how 'Doubting Sara' relates to the Qur'an - namely, that it is far better to read one verse thoughtfully and reflectively than a lengthy section hastily. This approach to the Qur'an distinguishes 'Doubting Sara' sharply from 'Pious Sara', for whom the mere act of reading is primary and understanding secondary.

When Sara encounters a Quranic passage that she finds difficult to understand, she turns to Google. However, she only examines Persian search results that link to views of Iranian Shi'a scholars - and more specifically to Iranian Shi'a scholars who are 'not in support of the Iranian state'. According to Sara, the Shi'a are much more moderate than the Sunni, and therefore she sticks to the Shi'a religious sources.

The interplay between the two I-positions explains well Sara's relationship to the marja' institution. Sara recognizes one Iranian Ayatollah as her marja' and adheres to his decisions in religious matters. At the same time, she points out the irony that, despite being highly critical of clerics who are involved in Iranian politics, she commits herself to following one such cleric. In fact, Sara is actively pondering whether the marja' institution is needed at all and whether it is legitimate for a Shi'a to reject it. Sara has read criticisms that reformminded Shi'a thinkers have directed towards the institution, but she has not yet made her own decision regarding the matter.

The inclusion of external I-positions in a dialogical self provides a fruitful approach for conceptualizing the role of religious authorities in identity construction. Religious authorities exist in the dialogical self as external I-positions, or in other words, as imaginary others that criticize, advise or encourage one's other positions. In Sara's case, the relationships within her dialogical self might appear something like Figure 1.

Using graphs like Figure 1 to represent a dialogical self is risky in that it may suggest the self is a stable psychological structure. In this article my aim is to argue for the contrary: the self is a dynamic system and responds to changes in its context (cf. Hermans and Gieser 2011: 25). In the 
following section, I discuss how a transition such as migration may lead to reorganization in the self and how such reorganization is accomplished through the use of symbolic resources.

\section{Symbolic resources in the service of self- making}

As the previous interview excerpt about her brother illustrates, the duality of Sara's self is linked to the duality of her cultural background. Sara was born of Afghan parents and spent her early years in Afghanistan. However, for most of her life, she has lived in Finland, and 'Doubting Sara' in particular is very much rooted in the Finnish cultural soil. When 'Doubting Sara' voices her reservations regarding her religious tradition, she justifies her doubts with a reference to the Finnish context: 'I think that the fact that I have moved here to Finland has an effect on this process as well. If I had been in Iran or Afghanistan, would I ... have pondered these same questions there?'

In the terminology of Tania Zittoun (2005: 5), Sara's early socialization context in Afghanistan and the subsequent socialization context in Finland constitute two distinct 'spheres of experience', that is, 'fields of activity ... in each of which [a person] meets specific actors, talks a given language, follows certain rules, develops certain intentions, and has as references some imaginary others'. Every person moves through several spheres of experience both in their everyday life and over the course of their life. Going home from work is perhaps the most mundane example of movement from one sphere of experience to another. Migration is another example, and one that is likely to have a profound effect on one's identity.

A transition between spheres may be smooth or, alternatively, it may be experienced as a rupture (Zittoun 2005: 5-6). In the latter case, a person may use symbolic resources to manage the resulting feelings of anxiety and uncertainty. Symbolic resources are 'shared concrete things, or some socially stabilized patterns of interaction or customs which encapsulate meanings or experiences for people' (Zittoun et al. 2003: 417). They are concrete artefacts (such as books or paintings) or abstract ideas (such as stories or values) that are used as psychological tools, for example in the regulation of emotion or in meaningmaking. An example from Sara's life is her favourite verse (Qur'an 13:28; trans. Abdel Haleem: 'those who have faith and whose hearts find peace in the remembrance of God - truly it is in the remembrance of God that hearts find peace') that she uses to remind herself of how God has helped her to get through 'the worst moments' of her life.

Combining DST and Zittoun's terminology (cf. de Abreu et al. 2013; Baucal and Zittoun 2013), transitions such as migration can be construed as developmental challenges to the self. The existing repertoire of I-positions may be inadequate in a novel sphere of experience, which is then experienced as uncertainty or even anxiety. For example, some of the discourses that are dominant in the Finnish context support norms and values that are in tension with the norms and values that Sara has learned to consider as 'Islamic'. 'Pious Sara' and other I-positions that are linked to Sara's childhood religious socialization cannot satisfactorily resolve the tension, which leads to her experiencing what she calls an 'identity crisis'.

As a self-organizing system, the self may mobilize its symbolic resources to restructure the position repertoire and make it better equipped to deal with the demands of the sphere of experience. In Sara's case, the I-position of 'Doubting Sara' emerges as 
Table 1. Key distinctions between 'Pious Sara' and 'Doubting Sara'

\begin{tabular}{|l|l|l|}
\hline \multirow{2}{*}{ Important in reading the Qur'an } & 'Pious Sara' & 'Doubting Sara' \\
$\begin{array}{l}\text { Sphere of experience } \\
\text { Key dialogue partners }\end{array}$ & Reciting & Understanding \\
Drghanistan, Iran & Finland \\
\hline Grandmother & $\begin{array}{l}\text { Father, brother, Ali Shariati, Elahi } \\
\text { Ghomshei, and Abdolali Bazargan }\end{array}$ \\
\hline
\end{tabular}

one of the loudest voices in her dialogical self. 'Doubting Sara' begins an active investigation into the issues that have introduced disequilibrium into the self. She discusses the issues with her brother and consults her father, whose advice leads her to look into views of religious progressives. The voices of thinkers like Abdolali Bazargan become integrated into Sara's dialogical self, and from them she gains valuable symbolic resources to manage her crisis.

\section{Motivational dynamics in the religious self}

In the third stage of NSM, attention is turned to the motives that drive the I-positions. According to Hermans (1999), such motives typically fall into two general categories: $\mathrm{S}$ motives are about selfenhancement and include strivings for strength, pride, self-esteem, self-confidence, etc. In contrast, $\mathrm{O}$ motives aim at a union with somebody else and involve such goals as caring, intimacy, love and tenderness. In order to grasp what motivates 'Doubting Sara' and 'Pious Sara', I examined their priorities in religion.

It is probably no surprise that Sara's two I-positions appear to be driven by differing motives. 'Doubting Sara' is characterized by striving for independence, autonomy and agency - in other words, typical S motives. In turn, 'Pious Sara' is driven above all by $\mathrm{O}$ motives, for example, comfort and peace of mind (see Table 1).

The interplay between the I-positions and the way in which they negotiate their divergent motives produce the dynamics of Sara's self. In Sara's inner dynamics, 'Doubting Sara' serves as the centrifugal force (see Figure 2). She raises difficult questions to which she feels compelled to find answers. In her quest for answers, 'Doubting Sara' expands her network of religious influences to include new scholars, both religious and non-religious. These include, for example, such highly original thinkers as Ali Shariati, Elahi Ghomshei and Abdolali Bazargan. In addition to learning about what others have said about the Qur'an, 'Doubting Sara' needs to understand the Qur'an for herself. For this purpose, she has read the Finnish translation of the holy book.

'Pious Sara', in turn, is the centripetal force of Sara's inner world. She is committed to the religious practices that she learned as a child and finds a great comfort in them. 'Pious Sara' turns to the Qur'an at times of distress, but not to any particular chapter or verse. According to 'Pious Sara', the act of reading in itself is what brings her relief and reassurance. For her, understanding the contents of the Qur'an is secondary to finding peace of mind from its recitation. Accordingly, her most important - albeit informal - religious authority is her grandmother, whom she very explicitly contrasts with the thinkers that have inspired her other I-position, 'Doubting Sara'. The grandmother is different from the scholars 

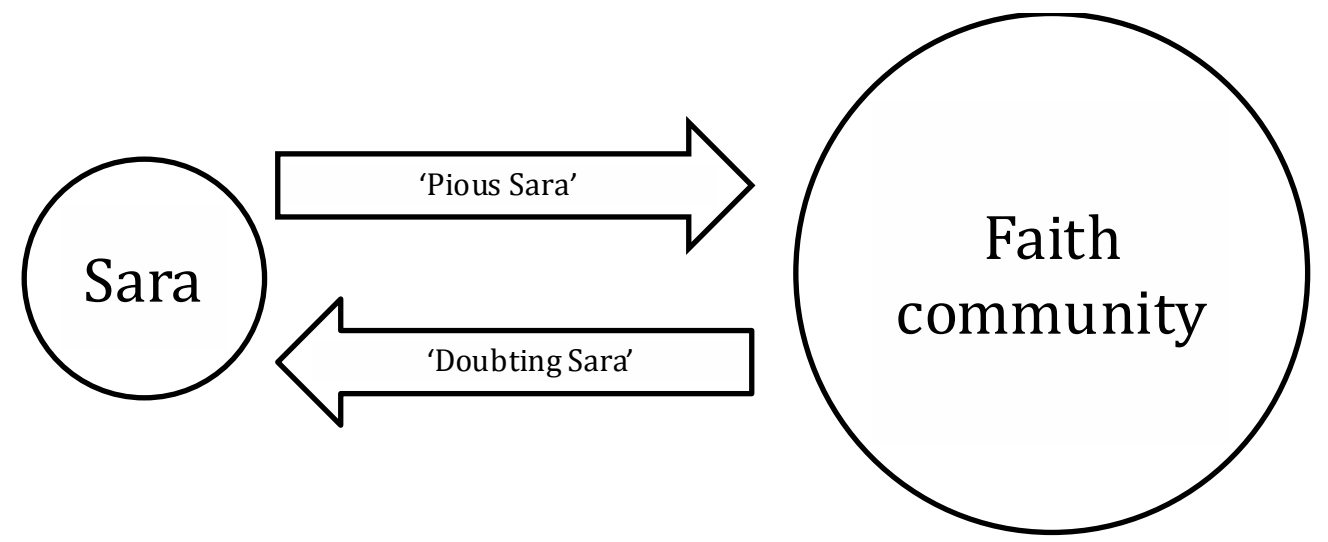

Figure 2. Maintenance of balance between religious stability and growth

in that she did not 'study' the Qur'an but 'just read' it so that it would bring blessings into the the lives of her grandchildren.

Together, 'Doubting Sara' and 'Pious Sara' provide both stability and change to Sara's religious life. 'Doubting Sara' challenges established truths and introduces new influences into Sara's worldview. As such, 'Doubting Sara' is a driver of religious growth. However, the religious quest in which 'Doubting Sara' is engaged could well take her away from Islam, were it not for the counterforce provided by 'Pious Sara'.

\section{Conclusion}

Research on European Muslims has provided extensive evidence of a change in how they relate to their religious tradition and its authorities. Younger, Europeanborn generations are increasingly reassessing the beliefs and values with which they have been brought up. In particular, young women challenge Muslim voices that they perceive as sexist and promote discourses of gender equality (see e.g. Karlsson Minganti 2008). The diversification of religious authority is further intensified by the internet and the ways in which it disrupts the religious status quo and allows new actors to gain influence. In today's world, a laptop may be more important than a degree in Sharia for getting one's religious views heard.

In this article, I have analysed the interview account of one young Muslim, 'Sara', and described how it manifests the plurality of potential authorities in the life of a young European Muslim. Sara's religious identity has been deeply affected by the everyday devotions of her grandmother. She has discussed and debated religious questions with her father and brother. She has read books, watched YouTube videos, and listened to recorded lectures of progressive Shi'a thinkers. She has read from the Qur'an in three different languages and gets Quranic verses into her Instagram feed. She acknowledges the religious authority of a marja, even though feeling somewhat uneasy about it.

Like participants in the studies of Amin (2019) and Tajri (2016), Sara has an ambivalent relationship with established religious authority. She is especially critical of Islamic scholars who have ties to the political establishment, and is actively looking for alternative views on religion. Importantly for research on European Shi ism, however, the influences from which she draws are part of the Shía discursive tradition. Despite all her criticism, Sara confines her religious search to Shi'a sources, abstaining 
for example from integrating explicitly Christian or even Sunni elements into her worldview. Like Amin's (2019) interviewees, Sara does not engage in a completely unrestricted bricolage but remains within certain boundaries that she herself has set. Furthermore, and corresponding to Tajri's (2016) findings, Sara's account demonstrates the enduring significance of transnational authority to European Shi'a; despite emphasizing the difference between living in Iran and living in Finland, Sara searches for religious information in Persian language and on the web pages of Iranian scholars.

In this article, my aim has been to introduce dialogical self theory (DST) as a fruitful approach to conceptualizing the ways in which young European Muslims negotiate their identities in relation to religious authorities in their lives. According to DST, the self is best understood as a dialogue among various voices, some of which are experienced as originating from inside one's own person while others are attributed to other people. The self is internally divided and decentralized, but each of its parts has its own role in the functioning of the whole. By including both intrapsychic and interpersonal identity negotiations, DST provides tools for capturing the complexity of identity dynamics. In addition, the position typologies outlined by Hermans and Gieser (2011) and Raggatt (2011) allow for a deeper understanding of the systemic function of each voice within the self.

DST is also helpful in making sense of ambiguities and contradictions in an interview data. According to DST, contradictory statements within an interview do not necessarily indicate that one of them is false. In contrast, the statements can all be true but for different I-positions. For example, Sara's two I-positions have different priorities in choosing a Qur'an, and therefore Sara can rightfully name two different Qur'ans as her preferred ones.

Besides being divided, a dialogical self is also dynamic and reorganizes itself in response to life experiences. In this article, I have described how symbolic resources can be used as psychological tools to manage uncertainty or to achieve a sense of coherence and meaning. Symbolic resources have a circular relationship with the I-positions: symbolic resources can be used to reorganize the position repertoire or to introduce new I-positions to it. For example, by reading Ali Shariati's books, Sara has familiarized herself with his thoughts and become able to engage in dialogue with them. In short, Ali Shariati has become an external I-position in Sara's dialogical self. In turn, integrating Ali Shariati into the dialogical self provides Sara with further symbolic resources, for example, arguments against the view of Islam as inherently misogynous.

Besides responding to external changes and challenges, a self has its own internal dynamic that maintains its activity and keeps the self from becoming stagnated. To elaborate on my prior astronomical metaphor, if Sara is a moon and her faith community a planet, 'Doubting Sara' and 'Pious Sara' provide the forces that keep them in motion and at a right distance from each other (see Figure 2). Without the centrifugal force of 'Doubting Sara', Sara's religious life would lose all momentum. Being left with no power to resist her religious upbringing, she would have no choice but to accept its male-centric and heteronormative values. In contrast, without the centripetal force of 'Pious Sara', Sara would lose connection with her faith community and be hurled to the Great Unknown without the religious resources on which she relies for reassurance.

To summarize the key points raised by the DST approach to religious authority: 
- Instead of being unidirectional, the relationship between a believer and a religious authority is dialogical. The role of an authority in a person's life is constantly negotiated and renegotiated.

- Similarly, the various religious authorities in a person's life exist in a dialogical relationship with each other. Specifically, the role of any single authority is in part determined by its actual or imagined interaction with other authorities. For example, in Sara's case, Abdolali Bazargan derives some of his legitimacy from being recommended by Sara's father.

- A person's self is not a single unified entity but a collection of relatively autonomous I-positions, each of which may relate differently to any given religious authority. In an interview account or other personal discourse, the dialogical relations between the I-positions may appear as ambivalence in relation to authority.

- Religious authorities can be conceptualized as external I-positions in a person's dialogical self.

- A person's dialogical self and therefore also their authority relations react to changes in life circumstances. As a dynamic system, the self may adapt to a changing situation by revising its existing position repertoire.

- As a self-organizing system, a dialogical self has an internal dynamic that keeps it evolving and developing. The development of the self is at least in part driven by an attempt to restore homoeostasis between competing needs and motives, for example, between a need for selfenhancement and a need for intimacy (cf. Pauha and Ronkainen 2021).
In closing, I would like to address a potential misunderstanding and emphasize that a dialogical self should not be confused with dissociative identity disorder or other mental illness. There is nothing pathological about a dialogical self. Instead, according to DST, a dialogue among several I-positions is constitutive of a normal psyche. Similarly, I perceive the interplay of Sara's different I-positions as an attempt to come to terms with a conflict that appears to be part of the human condition - namely, a conflict between the competing needs of autonomy versus union.

A similar conflict between $\mathrm{S}$ and $\mathrm{O}$ motives is described by Pauha and Ronkainen (2021) in a study on the identity of the Christian mixed martial arts professional Ron Waterman. At the end of their article, Pauha and Ronkainen (p. 12) conclude: 'Religion and sport exist in relative harmony in some passages of [Waterman's] life, whereas in other passages tensions arise. In Waterman's case, however, the conflict is not so much between Christianity and mixed martial arts per se, but between the motives that they serve.' In order to manage the conflict, Waterman adopts a third position; by joining a troupe of Christian bodybuilders, Waterman achieves a temporary balance between his needs of autonomy and needs of union.

Will Sara acquire a third position that will provide a resolution to her identity conflict? Maybe, maybe not. She may not even need one. As noted above, tensions among the I-positions are often benign or even beneficial to a well functioning psyche. Based on Sara's account and previous literature (see e.g. Hermans 1996; Hermans and Gieser 2011:21-2), I surmise that a key feature of a productive conflict between I-positions is their mutual power balance. As long as both 'Doubting Sara' and 'Pious Sara' have room to pursue their 
own needs, their interaction may serve as a driver for religious development. If either of the I-positions were to gain dominance, it could suffocate the other, which in turn would result in some vital needs going unfulfilled.

Teemu Pauha, Ph.D., is a psychologist and scholar of religion, with a focus on the social psychological study of religious identity and interreligious relations, particularly in the context of Islam in Europe. An overarching theme in his research is identity con-

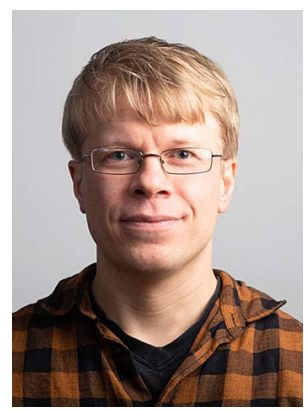

flict and its negotiation - both between people and within an individual. His current research topics include Shi'ism in Finland, Islamic eschatology and religion in sport. Besides his research work, Pauha has worked as a clinical psychologist in student health care and child psychiatry.

\section{References}

Abreu, Guida de, Ria O'Sullivan-Lago, and Hannah C. Hale. 2013. "Nowadays I Think, 'Wow: I made it"': exploring immigrant transitions drawing on dialogical self theory and the notion of symbolic resources', in Interplays Between Dialogical Learning and Dialogical Self, eds. M. Beatrice Ligorio and Margarida César (Charlotte; NC: Information Age Publishing), 127-49.

Amin, Hira. 2019. 'British Muslims navigating between individualism and traditional authority', Religions 10(6): 354, doi: <https:// doi.org/10.3390/rel10060354>.

Ammerman, Nancy T. 2007. Everyday Religion: Observing Modern Religious Lives (Oxford University Press).

Asad, Talal. 2017. 'L'idée d'une anthropologie de l'islam', Archives de sciences sociales des religions 180(4): 117-37, doi: <https://doi-org. libproxy.helsinki.fi/10.400o/assr.29724>.

Baucal, Aleksandar, and Tania Zittoun. 2013. 'Religion as dialogical resource: a sociocultural approach', Integrative Psychological and Behavioral Science 47(2):
207-19, doi: <https://doi.org/10.1007/ s12124-013-9229-Z>.

Bialecki, Jon. 2009. 'The bones restored to life: dialogue and dissemination in the Vineyard's dialectic of text and presence', in The Social Life of Scriptures: Cross-Cultural Perspectives on Biblicism, ed. James S. Bielo (New Brunswick, NJ: Rutgers University Press), 136-56.

Brekke, Torkel, Lene Kühle, Göran Larsson, and Tuomas Martikainen. 2019. 'Mosques, Muslims, methods: the role of mosques in research about Muslims in Europe', Journal of Muslims in Europe 8(2): 216-33, doi: <https://doi. org/10.1163/22117954-12341394>.

Campbell, Heidi. 2007. 'Who's got the power? Religious authority and the internet', Journal of Computer-Mediated Communication 12(3): 1043-62, doi: <https://doi.org/10.11 11/j.1083-6101.2007.00362.x>.

Dawson, Lorne L. 2006. 'Psychopathologies and the attribution of charisma: a critical introduction to the psychology of charisma and the explanation of violence in new religious movements', Nova Religio 10(2): 3-28, doi: $<$ https://doi.org/10.1525/nr.2006.10.2.3 $>$.

Dessing, Nathal M., Nadia Jeldtoft, Jørgen S. Nielsen, and Linda Woodhead. 2013. Everyday Lived Islam in Europe (London: Routledge).

Duderija, Adis. 2007. 'Literature review. Identity construction in the context of being a minority immigrant religion: the case of western-born Muslims, Immigrants \& Minorities 25(2): 141-62, doi: <https://doi. org/10.1080/02619280802018132>.

El-Yousfi, Amin. 2019. 'Conflicting paradigms of religious and bureaucratic authority in a British mosque', Religions 10(10): 564, doi: $<$ https://doi.org/10.3390/rel10100564>.

Flaskerud, Ingvild. 2018. "Street theology": vernacular theology and Muslim youth in Norway', Islam and Christian-Muslim Relations 29(4): 485-507, doi: <https://doi.org/1 $0.1080 / 09596410.2018 .1512286>$.

Grimell Jan. 2018. 'Advancing an understanding of selves in transition: I-positions as an analytical tool, Culture \& Psychology 24(2): 190-211, doi: <https://doi. org/10.1177/1354067X17707451>.

Hall, David D. 1997. 'Introduction', in Lived 
Religion in America: Toward a History of Practice, ed. David D. Hall (Princeton University Press), vii-xiii.

Hermans, Hubert J. M. 1996. 'Opposites in a dialogical self: constructs as characters', Journal of Constructivist Psychology 9(1): 1-26, doi: <https://doi. org/10.1080/10720539608404649>.

Hermans, Hubert J. M. 1999. 'Self-narrative as meaning construction: the dynamics of self-investigation, Journal of Clinical Psychology 55(10): 1193-1211, doi: $<$ https://doi.org/10.1002/(SICI)10974679 (199910) 55:10\% 3 C $1193:$ :AID JCLP $3 \%_{3} \mathrm{E}_{3}$.o.CO;2-I>.

Hermans, Hubert J. M. 2001. 'The dialogical self: toward a theory of personal and cultural positioning, Culture \& Psychology 7(3): 243-81, doi: <https//doi. org/10.1177/1354067X0173001>.

Hermans, Hubert J. M. 2014. 'Self as a society of I-positions: a dialogical approach to counseling, Journal of Humanistic Counseling 53(2): 134-59.

Hermans, Hubert J. M., and Thorsten Gieser. 2011. 'Introductory chapter. History, main tenets and core concepts of dialogical self theory', in Handbook of Dialogical Self Theory, eds. Hubert J. M. Hermans and Thorsten Gieser (Cambridge University Press), 1-22.

Hermans, Hubert J. M., Harry J. G. Kempen, and Rens J. P. van Loon. 1992. 'Dialogical self: beyond individualism and rationalism, American Psychologist 47(1): 23-33, doi: <https://doi. org/10.1037/0003-066X.47.1.23>.

Hjarvard, Stig. 2016. 'Mediatization and the changing authority of religion', Media, Culture and Society 38(1): 8-17, doi: <https:// doi.org/10.1177/0163443715615412>.

Jacobsen, Christine M. 2011. Islamic Traditions and Muslim Youth in Norway (Leiden: Brill).

Karlsson Minganti, Pia. 2008. 'Becoming a "practising Mus

lim": reflections on gender, racism and religious identity among women in a Swedish Muslim youth organisation', Elore 15(1): 1-16, doi: $<$ https://doi.org/10.30666/elore.78705>.

Kramer, Gudrun, and Sabine Schmidtke. 2006. Speaking for Islam: Religious Authorities in Muslim Societies (Leiden: Brill).
Lévi-Strauss, Claude. 1962. La pensée sauvage (Paris: Plon).

McGuire, Meredith. 2008. Lived Religion: Faith and Practice in Everyday Life (New York: Oxford University Press).

Mandaville, Peter. 2007. 'Globalization and the politics of religious knowledge: pluralizing authority in the Muslim world, Theory, Culture and Society 24(2): 101-5, doi: <https:// doi.org/10.1177/0263276407074998>.

Nir, Dina. 2011. 'Voicing inner conflict: from a dialogical to a negotiational self', in Handbook of Dialogical Self Theory, eds. Hubert J. M. Hermans and Thorsten Gieser (Cambridge University Press), 284-300.

Pauha, Teemu. 2018. Religious and National Identities among Young Muslims in Finland: A View from the Social Constructionist Social Psychology of Religion, PhD dissertation, University of Helsinki, <http://urn.fi/ URN:ISBN:978-951-51-4451-5>.

Pauha, Teemu, and Abbas Bahmanpour. Forthcoming. 'Shiialaisuus Suomessa', in Suomalaiset muslimit, eds. Teemu Pauha and Johanna Konttori (Helsinki: Gaudeamus).

Pauha, Teemu, and Iiris Nikanne. 2022. 'Finland', in Yearbook of Muslims in Europe, Volume 13, eds. Stephanie Müssig, Egdūnas Račius, Samim Akgönül, Ahmet Alibašić, Jørgen S. Nielsen, and Oliver Scharbrodt (Leiden: Brill), 218-34.

Pauha, Teemu, and Noora Ronkainen. 2021. " "Strong and courageous" but "constantly insecure": dialogical self theory, intersecting identities, and Christian mixed martial arts', Qualitative Research in Sport, Exercise and Health, doi: <https://doi.org/10.1080/2 159676X.2021.1937297>.

Peter, Frank. 2006. 'Individualization and religious authority in Western European Islam', Islam and Christian-Muslim Relations 17(1): 105-18, doi: <https://doi. org/10.1080/09596410500400165>.

The Qur'an: English Translation and Parallel Arabic Text, trans. M. A. S Abdel Haleem (Oxford University Press, 2010).

Raggatt, Peter T. F. 2011. 'Positioning in the dialogical self: recent advances in theory construction, in Handbook of Dialogical Self Theory, eds. Hubert J. M. Hermans and Thorsten Gieser (Cambridge University Press), 29-45. 
Reinhart, A. Kevin. 2020. Lived Islam: Colloquial Religion in a Cosmopolitan Tradition (Cambridge University Press).

Rinallo, Diego, Pauline Maclaran, and Lorna Stevens. 2016. 'A mixed blessing: market-mediated religious authority in neopaganism', Journal of Macromarketing 36(4): 425-42, doi: <https://doi. org/10.1177/0276146716655780>.

Schielke, Samuli. 2010. 'Second thoughts about the anthropology of Islam, or how to make sense of grand schemes in everyday life, ZMO Working Papers 2, <http://www. zmo.de/publikationen/WorkingPapers/ schielke_2010.pdf>.

Schielke, Samuli, and Liza Debevec. 2012. Ordinary Lives and Grand Schemes: An Anthropology of Everyday Religion (New York: Berghahn Books).

Stephenson, Lisa P. 2011. 'Prophesying women and ruling men: women's religious authority in North American Pentecostalism, Religions 2(3): 410-26, doi: <https://doi. org/10.3390/rel2030410>.

Tajri, Muhammed. 2016. 'Assessing perceptions of Islamic authority amongst British Shi'a Muslim youth', in Muslims in the UK and Europe II, eds. Yasir Suleiman and Paul Anderson (Cambridge: Centre of Islamic Studies, University of Cambridge), 148-56, <http://www.cis.cam.ac.uk/wp-content/ uploads/2016/05/MUKE-Text-PublicationMASTER.pdf $>$.

Takim, Liyakatali. 2006. The Heirs of the Prophet: Charisma and Religious Authority in Shi'ite Islam (Albany: State University of New York Press).

Thorne, Avril. 2004. 'Putting the person into social identity', Human Development 47(6): 361-5, doi: <https://doi. org/10.1159/000081038>.

Voas, David, and Fenella Fleischmann. 2012. 'Islam moves west: religious change in the first and second generations', Annual Review of Sociology 38: 525-45, doi: <https://doi. org/10.1146/annurev-soc-071811-145455>.

Walbridge, Linda S. 2001. The Most Learned of the Shi'a: The Institution of the Marja' Taqlid (New York: Oxford University Press).

Wright, Paul John. 2008. 'Predicting reaction to a message of ministry: an audience analysis', Journal for the Scientific Study of Religion
47(1): 63-81, doi: <https://doi.org/10.111 $1 / j .1468-5906.2008 .00392 . x>$.

Zittoun, Tania. 2005. Transitions: Symbolic Resources in Development (Greenwich: Information Age Publishing).

Zittoun, Tania, Gerard Duveen, Alex Gillespie, Gabrielle Ivinson, and Charis Psaltis. 2003. 'The use of symbolic resources in developmental transitions', Culture \& Psychology 9(4): 415-48, doi: <https://doi. org/10.1177/1354067X0394006>. 